\title{
EVALUATION METHOD OF ATHLETES' SPECIAL PHYSICAL FITNESS BASED ON INTERNET OF THINGS
}

\author{
MÉTODO DE AVALIAÇÃO DA ADEQUAÇÃO FÍSICA ESPECIAL DOS ATLETAS BASEADO NA INTERNET \\ DAS COISAS \\ MÉTODO DE EVALUACIÓN DE LA APTITUD FÍSICA ESPECIAL DE LOS ATLETAS BASADO EN LA INTERNET \\ DELASCOSAS
}

\begin{abstract}
Jinling Li'
(Public Health Education)

1. Common Course Teaching Department, Shandong University of Arts, Jinan 250014, Shandong, China.
\end{abstract}

\section{Correspondence:}

Shandong, China.zicbss@163.com

\begin{abstract}
Special physical fitness plays an important role in sports skills, improving athletic performance and preventing injuries. Based on the Internet of Things (loT), the method of assessing athletes'specific physical fitness is studied using the linear acceleration energy estimation model. After relevant research on the athletes'real training environment, a real-time monitoring platform is designed. Besides, the MQVA algorithm is proposed, and the simulation experiment is designed. Finally, the accuracy of several algorithms is verified by the practical method of evaluating the application. The verification results show that the precision of the algorithm and the model achieve the expected results. An evaluation model is proposed for individual athletes of the training effect based on the energy consumption rate; for multi-athletes, the indicators used are the progress of energy transfer. This model is compared and verified employing examples. The results show that the evaluation model is accurate and reliable. This investigation is part of the contents of the investigation of the physical fitness training system of the potential advantage project in China. It can provide a theoretical basis for coaches to adopt effective special physical training approaches and methods.
\end{abstract}

Keywords: Internet of things; athletes; special physical fitness.

\section{RESUMO}

A aptidão física especial tem um papel importante no domínio das habilidades esportivas, melhorando o desempenho atlético e prevenindo as lesões. Baseado na Internet das Coisas (IOT), o método de avaliação de aptidão física específica dos atletas é estudado usando o modelo de estimativa de energia de aceleração linear. Após uma pesquisa relevante sobre o ambiente de treinamento real dos atletas, é projetada uma plataforma de monitoramento em tempo real adequada para treinamento de atletas. Além disso, o algoritmo MQVA é proposto e é projetado o experimento de simulação. Finalmente, a precisão de vários algoritmos é verificada pelo método prático de avaliação da aplicação. Os resultados da verificação mostram que a precisão do algoritmo e o modelo alcançam os resultados esperados. Propõe-se um modelo de avaliação do efeito de formação baseado na taxa de consumo de energia para atletas individuais. Para multi-atletas se usam os indicadores de avaliação do progresso da transferência de Energia. Este modelo é comparado e verificado por meio de exemplos. Os resultados mostram que o modelo de avaliação é preciso e confiável. Esta investigação faz parte dos conteúdos da investigação do sistema de formação de aptidão física do projeto potencial de vantagem na China. O mesmo pode fornecer uma base teórica para que os treinadores adoptem abordagens e métodos de formação física especial eficazes.

Descritores: Internet das coisas; atletas; aptidão física especial.

\section{RESUMEN}

La aptitud fisica especial tiene un papel importante en el dominio de las habilidades deportivas, mejorando el desempeño atlético y previniendo las lesiones. Basado en la Internet de las Cosas (IoT), el método de evaluación de aptitud física específica de los atletas es estudiado usando el modelo de estimativa de energía de aceleración lineal. Después de una importante investigación sobre el ambiente de entrenamiento real de los atletas, es proyectada una plataforma de monitoreo em tiempo real adecuada para entrenamiento de atletas. Además de eso, el algoritmo MQVA es propuesto y es proyectado el experimento de simulación. Finalmente, la precisión de varios algoritmos es verificada por el método práctico de evaluación de la aplicación. Los resultados de la verificación muestran que la precisión del algoritmo y el modelo alcanzan los resultados esperados. Se propone un modelo de evaluación del efecto de formación basado en la tasa de consumo de energía para atletas individuales. Para multi-atletas se usan los indicadores de evaluación del progreso de la transferencia de energía. Este modelo es comparado y verificado por medio de ejemplos. Los resultados muestran que el modelo de evaluación es preciso y confiable. Esta investigación hace parte de los contenidos de la investigación del sistema de formación de aptitud física del proyecto potencial de ventaja en la China. El mismo puede proporcionar una base teórica para que los entrenadores adopten abordajes y métodos de formación física especial eficaces.

Palabras clave: Internet de las cosas; atletas; aptitud física especial 


\section{INTRODUCTION}

The Olympic Games are excited by the slogan "faster, higher and stronger", so that every country or nation regards the sports achievements created by each athlete as a symbol of their own value, to stimulate self-confidence and a sense of pride. Therefore, the modern sports training for the creation of excellent special sports achievements has been highly valued and recognized by various countries. The development of the modern Olympic movement has been accompanied by the continuous endeavor to a higher level. Whether athletes have sufficient strength to participate in the competition depends on their competitive ability, which is a comprehensive ability of athletes to compete and is the comprehensive performance of interaction of athletes' physical, technical, tactical, psychological ability and sports intelligence in the process of the special training and competition. ${ }^{2}$ However, as the current development of major technology has been basically finalized, the training conditions are gradually approaching, the level of skills and tactics is almost the same, and the technical differences in the high-level competitions of most projects dominated by physical fitness are small, physical fitness becomes the key to success. The athlete's physical performance is expressed in the sports qualities like speed, strength, endurance, flexibility, sensitivity and the level of various qualities combined between them. ${ }^{3}$ These sports qualities only can provide athletes with the possibility of improving their athletic performance if they meet the needs of special project characteristics and special development. Therefore, the study of special physical fitness is of great significance to improve athletic performance.

Based on the loT, the assessment method of athletes'specific physical fitness is studied. First, the linear acceleration energy estimation model of the loT is constructed. After the relevant research on the actual training environment of athletes, a real-time monitoring platform suitable for athlete training is designed. Moreover, the MQVA algorithm is proposed. In a collaborative multi-agent system, each agent can be considered to "know" as much as possible to complete the task. In this way, what the agent can do is to adopt a reasonable strategy to transfer the environment from the current joint state to the state of being as "good" as possible, thereby achieving collaboration. Therefore, the "good" state is defined with the expected cumulative reward value. The larger the value, the more "good" the state, and the simulation experiment is designed.

\section{RELATED WORK}

In recent years, research on athletes' physical fitness and special physical fitness has become an area of great importance to the academic community. Marinho B F et al. regard physical fitness as the innate genetic quality of athletes and the ability that athletes trained perform continuous movements in special sports. ${ }^{4}$ Mostaghim N et al. believe that physical fitness referred to the combination of various physical exercise abilities that athletes need to improve their athletic skills and tactics and to create excellent athletic performance. ${ }^{5}$ Slimani M et al. hold the view that physical fitness is the athletic ability expressed through the skeletal muscle system based on the energy metabolism activities of the three major energy-supplied systems. ${ }^{6}$ Catikkas $F$ et al., based on the current situation that "They value skill over physical ability" in the training of table tennis in China, analyzed the importance of physical training in table tennis and proposed various methods of special physical training?

\section{TEST APPLICATION OF SPECIAL PHYSICAL FITNESS ASSESSMENT ALGORITHM}

\section{Data Sources}

In the process of testing the special physical fitness assessment algorithm constructed, data is collected. Six athletes (male) and world elite athletes of the 07th and 08th sprint special classes of Xi'an Physical
Education Institute are taken as the research object. Among six athletes of the sprint special projects, there are three athletes at the national level and three athletes at the second level. The specific information of the six athletes of the 07 and 08 sprint special classes of Xi'an Sports Institute are shown in Figure 1.

In this experiment, the athletes are tested by three-dimensional force measuring table and high-speed camera to obtain the kinematics and dynamic parameters of the swinging leg support stage before the jump, and the image data between the swinging leg support stage and the take-off stage. The instrument used in the experiment is the Swiss KISTLER three-dimensional force measuring table (the position is shown in Figure 2).

First of all, the aperture and focal length is debugged to make the best picture possible, which is convenient for analytical analysis and reduce the error. Before the game, the Aijie 3D radiation stereo frame placed in the shooting center is first filmed. Then the frame is filmed once the game is over, to prevent accidents. The high-speed camera and the force-measuring platform are started before the athletes run, to collect the monitoring video at the beginning and end stages. And the machine cannot be stopped and touched in the middle, in order to shoot the complete technology required.

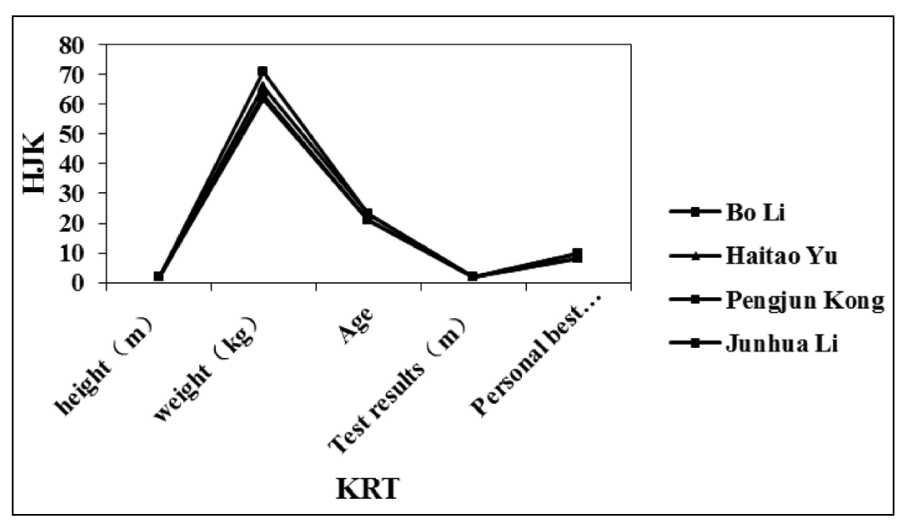

Figure 1. Overview of the basic situation of the research objects.

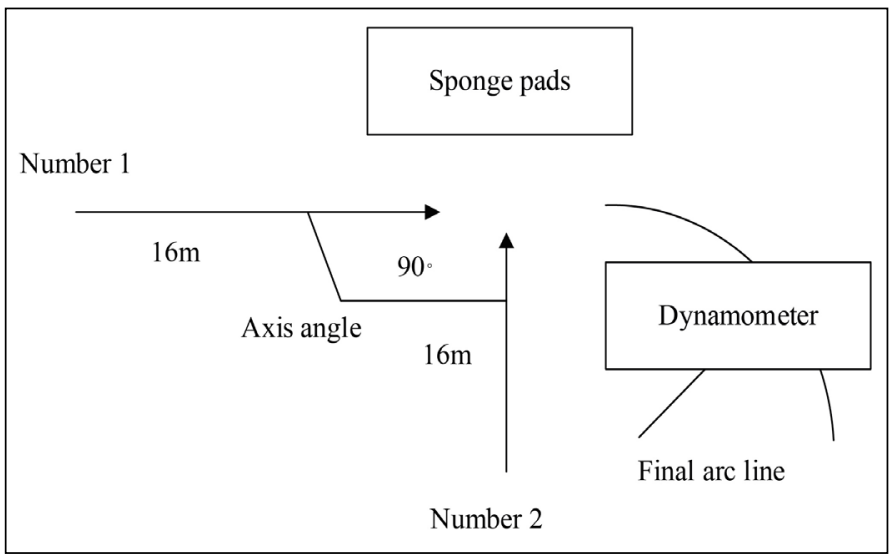

Figure 2. Scene map of high jump shooting.

\section{TEST RESULTS}

In the evaluation model of the individual training effect based on the training energy consumption rate proposed in the previous section, the core is to obtain the energy consumption rate $\mathrm{Q}$ and realize the evaluation of the training. In the following, based on the measured energy consumption value of the research object in the physical training process, the calculation of the training effect evaluation model is performed. As mentioned above, in order to facilitate the analysis and calculation, the energy consumption rate is the training data collected per 30S. The energy consumption rate of an athlete's continuous training for 10 minutes is shown in Table 1. 
According to the process of calculating the model in the formula, the above energy consumption rate value is first divided into four state spaces, that is, $m=4$. From the training limit energy consumption rate, it can be obtained that the steady state energy consumption rate of this athlete under the current training state is $5.602 \mathrm{kca} / 30 \mathrm{~S}$. According to the plot comparison of this limit energy consumption rate and energy consumption rate of athletes at each time node, the figure is obtained.

From Figure 3, the athlete's energy consumption rate has been lower than the limit energy consumption rate of $5.602 \mathrm{kca} / 30 \mathrm{~S}$ from the $450 \mathrm{~S}$. The figure shows that the law is consistent with that the actual training energy consumption rate rises and then decrease with the change of time. It is judged that the energy consumption rate of the athlete begins to decrease at the time of $5.602 \mathrm{kca} / / 30 \mathrm{~S}$, and the physical energy consumption is in an overdraft state. As an organization trainer, all kinds of physical changes and test data of athletes should be timely recorded. At the same time, it should be recommended that this athlete gradually reduce the amount of training, and if necessary, stop physical training for rest and ensure that physical training accidents cannot occur. And trainer should be responsible for communicating with the real-time monitoring terminal, receiving the request and command from the real-time monitoring terminal and returning relevant data (such as athlete's training

Table 1. Energy consumption rate of 10 minutes for a soldier's physical fitness training.

\begin{tabular}{c|c|c|c}
\hline Time (second) & $\begin{array}{c}\text { Energy consumption } \\
\text { rate (kcal/30s) }\end{array}$ & Time (second) & time (second) \\
\hline 30 & 3.642 & 330 & 6.296 \\
\hline 60 & 4.017 & 360 & 7.208 \\
\hline 90 & 3.946 & 390 & 6.863 \\
\hline 120 & 4.129 & 420 & 5.921 \\
\hline 150 & 5.136 & 450 & 4.498 \\
\hline 180 & 5.688 & 480 & 4.032 \\
\hline 210 & 5.743 & 510 & 3.823 \\
\hline 240 & 4.287 & 540 & 4.025 \\
\hline 270 & 5.728 & 570 & 3.121 \\
\hline 300 & 6.824 & 300 & 2.688 \\
\hline
\end{tabular}

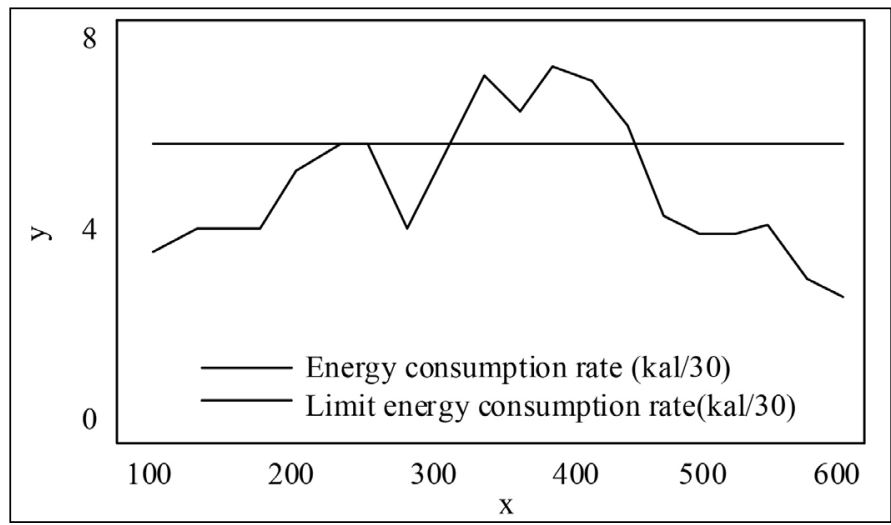

Figure 3. Comparison of consumption rate of internal consumption and limit energy consumption rate. data information, etc.) to the terminal, or sending the message to the data stream server after receiving the message request and then handing over to the communication service terminal of hardware communication base station. For the recognition of the training method, a basketball team sent 20 athletes to do the test, including 12 male athletes and 8 female athletes in the test sample. The basic information data of the 20 athletes is added to the database in the manner of Figure 5. And the measured data results judged by judged by the platform to the training mode are shown in Table 2 below.

Jump training has the highest discrimination rate. In 200 times jump training, 198 times are correctly identified, and the accuracy rate is 99\%, indicating that the algorithm is very effective for the identification of jumping motion. As the standing long jump in the jumping movement, 100 times are identified and the accuracy rate reached 100\%. While for another type of jumping movement, the run-up long jump, 98 times are accurately identified and the correct rate reached $98 \%$. That indicates that the algorithm not only has a high recognition rate for jumping projects, but also for standing long jumps and running jumps. Then the $1 \%$ error may be due to the athlete's athletic posture. From the data, the correct rate of recognition of the constant speed is also high. 97 times

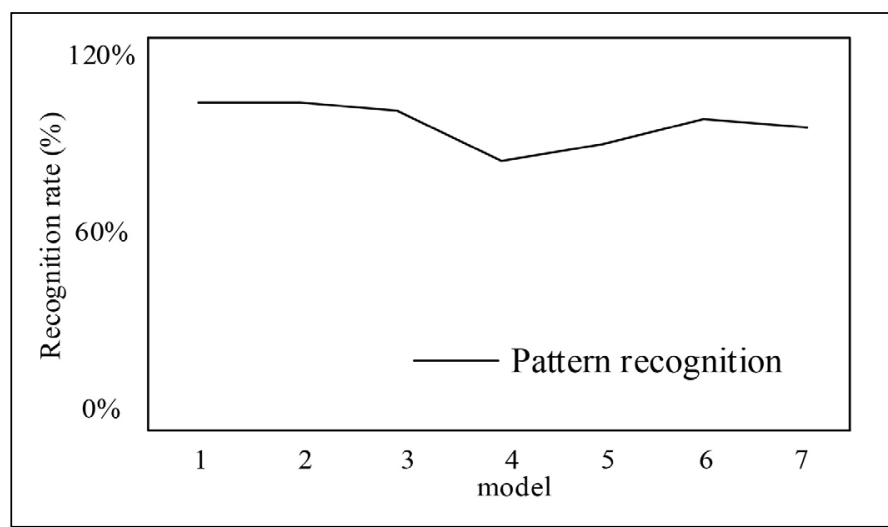

Figure 4. Training mode identification of columnar statistics.

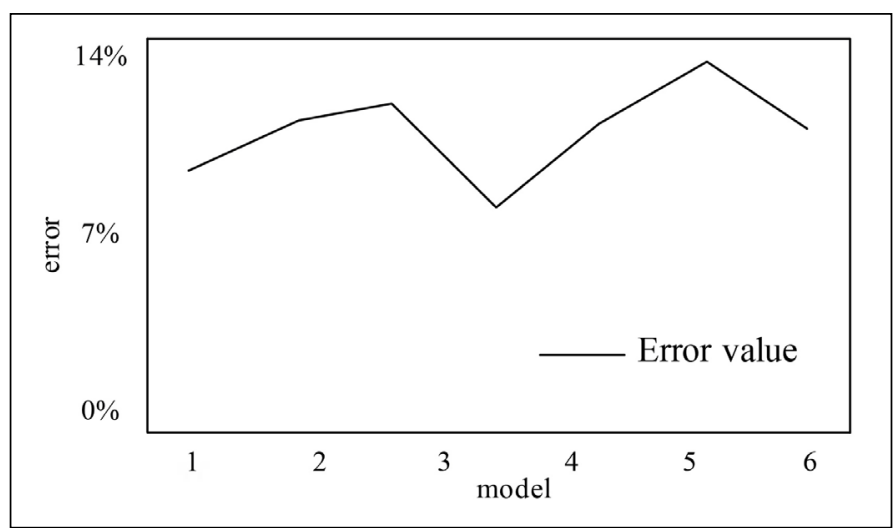

Figure 5. Training mode identification of columnar statistics.

Table 2. Training pattern recognition statistics.

\begin{tabular}{c|c|c|c|c|c|c|c}
\hline training program & $\begin{array}{c}\text { Think it's a long } \\
\text { jump (second) }\end{array}$ & $\begin{array}{c}\text { It is thought to } \\
\text { be a run-up long } \\
\text { jump (second) }\end{array}$ & $\begin{array}{c}\text { Think it's a } \\
\text { constant speed }\end{array}$ & $\begin{array}{c}\text { Think it's a quick } \\
\text { walk (second) }\end{array}$ & $\begin{array}{c}\text { Think it's a slow } \\
\text { run (time) }\end{array}$ & $\begin{array}{c}\text { Think it's a quick } \\
\text { run (time) }\end{array}$ & $\begin{array}{c}\text { Total number } \\
\text { of times }\end{array}$ \\
\hline Standing long jump & 100 & 0 & 0 & 0 & 0 & 0 & 100 \\
\hline Run-up long jump & 2 & 98 & 0 & 0 & 0 & 0 & 100 \\
\hline Constant speed & 0 & 0 & 97 & 2 & 1 & 0 & 1 \\
\hline Quick walk & 0 & 0 & 4 & 83 & 12 & 1 & 100 \\
\hline Slow running & 0 & 0 & 1 & 10 & 87 & 2 & 100 \\
\hline Fast running & 0 & 0 & 0 & 0 & 5 & & 95 \\
\hline
\end{tabular}


of the 100 normal speed movements are recognized, and the correct rate is $97 \%$, showing that the accuracy rate is also high. However, there are still two times that it is considered to be a quick walk, and one time is considered to be a slow run. The occurrence of such errors may be related to the athlete's walking habits. The energy consumption value is the parameter that must be obtained in the training effect evaluation model. The accurate extraction directly affects the authenticity of the evaluation index. The data is still the energy consumption data measured by training the 20 athletes in the previous section. The energy consumption value calculated by the Meijer formula is adopted to accurately evaluate the energy consumption value estimated by the linear acceleration model. The basic parameters of the 20 athletes are shown in Table 3.

In particular, the energy consumption for jump training takes the total energy consumption of 5 jumps as the research unit. The linear acceleration energy model is used to estimate and compare the energy consumption value calculated by the Meijer formula. The comparison chart of the energy consumption models under the six motion modes from the data in the table is shown as follows:

In the Figure 6, it is shown that the difference of energy consumption estimation between the normal speed walking and fast running is relatively large, and is $11.53 \%, 13.14 \%$, respectively, followed by run-up jump and slow-running. For the fast walking and the standing long jump, although there are certain errors in the two training energy consumption estimation, the error rate is smaller than the other training methods. From the perspective of the gender of the participants, the estimated error rate of male athletes' training energy consumption is smaller than that of female athletes. Under the same amount of training, the training energy consumption in horizontal and vertical can increase with the increase of weight. A large number of data comparison studies have found that the energy consumption of the constant speed and fast running training methods is most likely to be underestimated. The

Table 3. Physical parameters of 20 soldiers.

\begin{tabular}{c|c|c}
\hline \multirow{2}{*}{ Body index } & Male soldiers & Female soldier \\
\cline { 2 - 3 } & $\begin{array}{c}\text { mean value } \pm \text { standard } \\
\text { deviation }\end{array}$ & $\begin{array}{c}\text { mean value } \pm \text { standard } \\
\text { deviation }\end{array}$ \\
\hline Weight $(\mathrm{kg})$ & $72.3 \pm 11.2$ & $57.1 \pm 8.8$ \\
\hline Height $(\mathrm{cm})$ & $173.4 \pm 7.1$ & $165.6 \pm 4.2$ \\
\hline Age $(\mathrm{y})$ & $20.3 \pm 2.5$ & $21.0 \pm 2.8$ \\
\hline $\mathrm{BMl}\left(\mathrm{kg} / \mathrm{m}^{2}\right)$ & $24.3 \pm 3.5$ & $25.3 \pm 2.6$ \\
\hline
\end{tabular}

reason is that the vertical change is the most important component of the acceleration of the human body. The cause of the error is likely to be that the model underestimates the vertical energy consumption. For the movement that jumping is a kind of aperiodic process, it is relatively complicated, especially combined with running and standing jumping action to run long jump. So the cause of error may be caused by underestimating the complexity of the action.

\section{CONCLUSION}

The realization of the collection, monitoring and analysis evaluation function for athletes'special physical fitness training data is inseparable from the loT platform. The overall architecture of platform proposed includes several parts of the monitoring terminal, hardware communication base station, data analysis server and handheld monitoring terminal, which realizes real-time transmission of multiple physical fitness training data. And the evaluation and recommendations for training effect are given through data analysis. Here, six athletes from Xi'an Sports Institute are selected as the research objects. After the motion capture and auxiliary physical fitness monitoring and calculation of the 100-meter sprint movements of six subjects, the following conclusions are drawn. The complete training method recognition algorithm and step counting algorithm proposed by the training platform based on the loT can be used to evaluate the specific physical fitness training of single athletes and multiple athletes. The concept based on energy consumption evaluation is proposed. Based on Markov model, the training process is analyzed to find that the state time relationship in the motion process belongs to the discrete stochastic process. The single athlete physical fitness evaluation model based on the energy consumption rate provides the ultimate energy consumption rate and the limit training time for the individual athletes' physical training, which can provide differentiated evaluation and training advice for individual athlete training scientifically and impartially. The multi- athlete physical fitness evaluation model based on the energy rate transfer progress degree proposed uses the physical fitness transfer progress as index to eliminate the influence that causes by the physical fitness difference of multi-athlete physical training on the evaluation results, achieving a relatively fair evaluation. The shortcoming of this research is that the number of research objects is chosen too small, which may lead to inaccurate results and needs further improvement in the future.

The author declare no potential conflict of interest related to this article

AUTHORS' CONTRIBUTIONS: The author has completed the writing of the article or the critical review of its knowledge content. This paper can be used as the final draft of the manuscript. Every author has made an important contribution to this manuscript. Jinling Li: writing and execution.

\section{REFERENCE}

1. Bukhala P, Toriola AL, Onywera V. Assessment of physical fitness status of athletes with intellectual disabilities participating in special olympics programs in Nairobi County, Kenya. Journal of Human Ecology (Delhi, India). 2017;59(2-3):148-55.

2. Huang HC, Wu WL, Chang YK, Chu IH. Physical fitness characteristics of adolescent wushu athletes. J Sports Med Phys Fitness. 2018;58(4):399-406.

3. Simon JE, Docherty $\mathrm{CL}$. The impact of previous athletic experience on current physical fitness in former collegiate athletes and noncollegiate athletes. Sports Health. 2017;9(5):462-468.

4. Marinho B F, Follmer B, Esteves JV, Andreato LV. Body composition, somatotype, and physical fitness of mixed martial arts athletes. Sport Sciences for Health. 2016;12(2):157-65.

5. Mostaghim N, Jahromi MK, Shirazzi ZR, Salesi M. The effect of quadriceps femoris muscle Kinesio Taping on physical fitness indices in non-injured athletes. J Sports Med Phys Fitness. 2016;56(12):1526-33.

6. Slimani M, Chamari K, Miarka B, Del Vecchio FB, Chéour F. Effects of plyometric training on physical fitness in team sport athletes: a systematic review. J Hum Kinet. 2016;53:231-47.

7. Catikkas F. Sexual dimorphism in physical fitness parameters of competitive adolescent taekwondo athletes. Anthropologist, 2016;25(1):70-5. 